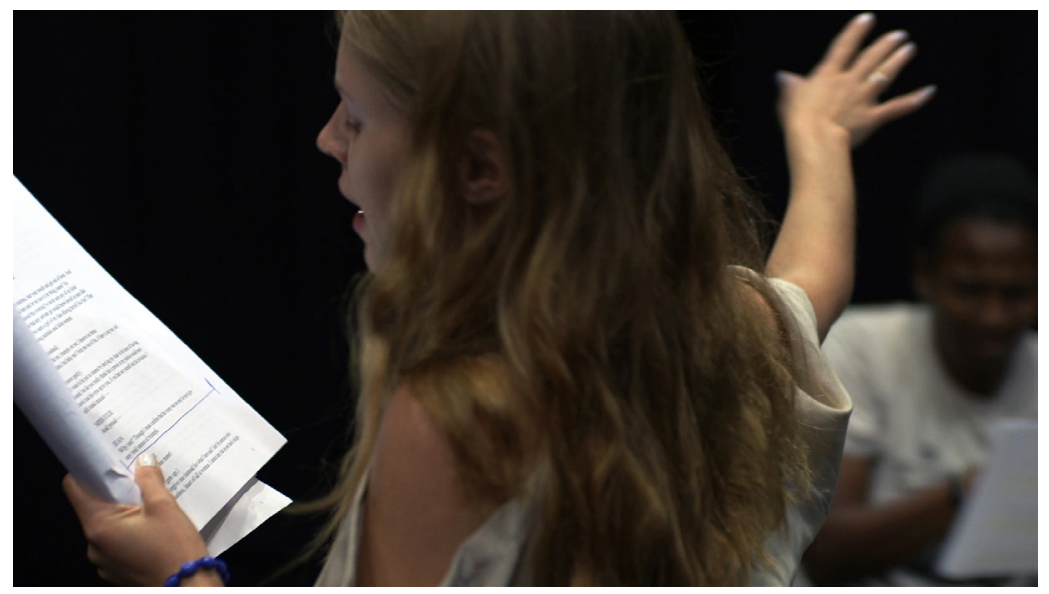

Alexandra Dahlström rehearsing her role as Alexandra/Julie at The Schoolhouse Theater, Croton Falls, New York. Still from Fia-Stina Sandlund's film She's Staging It, 20I 2. Photographer: Marius Dybwad Brandrud. Copyright CC-BY-NC-ND. 


\section{From Here to Eternity: Miss Julie Strikes Back and Refuses to Die}

Arrange for the bored and possibly clueless daughter of a count to find herself in the presence of a handsome servant with social ambitions. Add a maid who represents order, morality, and common sense. Immerse them in the Swedish midsummer night with its atmosphere of sexuality and magic. The result is the August Strindberg classic, Miss Julie, a play that has never ceased to fascinate directors, actors, and audiences since it was first staged in Copenhagen in I 889. ${ }^{\mathrm{I}}$

It has long been claimed that A Doll's House was the world's most performed play. Today Miss Julie seems about to edge Henrik Ibsen's drama from the top position. European theatres have recently presented Miss Julie in a variety of interpretations, including a British update by Patrick Marber directed by Natalie Abrahami at Young Vic in London; a multimedia version by Katie Mitchell and Leo Warner at the Schaubühne in Berlin; and a French mise-en-scène by Frédéric Fisbach, in which Juliette Binoche makes one of her rare appearances on stage. The Schaubühne's director and CEO, Thomas Ostermeier, has set his Miss Julie in contemporary Moscow. As in the same director's earlier productions of A Doll's House and Hedda Gabler, Miss Julie is trapped in a claustrophobic middle-class setting from whose social patterns she is unable to break free. The Russian Julie is the spoiled daughter of a former KGB officer who is now a nouveau-riche businessman living in luxury and opulence. We have watched Ostermeier's Nora and Hedda go under, and now it is Julie's turn to die.

When Sweden observed the centennial of Strindberg's death in $20 \mathrm{I} 2$, some greeted the upcoming celebration with skepticism and an air of boredom. There had already been a wide-ranging

How to cite this book chapter:

Rosenberg, Tiina 20I6. From Here to Eternity: Miss Julie Strikes Back and Refuses to Die. In: Rosenberg, Tiina Don't Be Quiet, Start a Riot! Essays on Feminism and Performance. Pp. I66-I74. Stockholm: Stockholm University Press. DOI: http://dx.doi.org/Io.I6993/baf.h. License: CC-BY 4.0 
discussion about women playwrights whose works, after being performed in the I 88 os, were then overshadowed by Strindberg, and had only recently been rediscovered and brought to the stage once more. What could possibly be new about Strindberg? Mounting Strindberg in Sweden has mainly come to mean two things: first, performing the canonized repertoire, and second, having one of the players impersonate Strindberg himself. No other Swedish playwright or author has been so identified with his characters as Strindberg. For a long time, it was axiomatic that male protagonists in productions of Strindberg's plays wore the Strindberg mask: a mustache, a trim goatee, and a suspicious gaze. ${ }^{2}$ In foreign productions audiences are typically given a wider breadth of interpretation as directors and actors can move more freely outside the Swedish national tradition. But the centennial has not been as predictable as one might have imagined. Three exciting feminist multimedia productions of Miss Julie, the play that has been one of the year's darlings, bear a closer look.

In Strindberg's own performance space, Intima Teatern (The Intimate Theatre) in Stockholm, Anna Pettersson offered a virtuoso solo performance in $20 \mathrm{I} 2$, in which she played the actress-director and the three roles of Julie, Jean, and Kristin. The audience entered to find an open curtain that revealed a classic Miss Julie setting: a kitchen table, an open window with curtains stirred by a summer breeze, and Swedish midsummer music playing in the background. But as soon as Pettersson came out the atmosphere changed radically. As she cleared all the props from the stage, a straight razor was projected on a large screen, and she began to wonder aloud how she will ever make it through the play. She waved a symbolic Strindberg about in the form of a book, raising questions about certain passages in the drama, performing parts of scenes, and testing the characters - all in a lively exchange with the audience.

In a theatre talk that followed the show, Pettersson revealed that she had originally intended to stage Miss Julie with three actors, but then decided to perform all three roles herself. She subsequently added the character of Anna, an actress, director, and contemporary woman who raises her voice in protest, but still engages with the Strindberg legacy. Pettersson's production 
of Miss Julie, given as part of the artistic research program at the Stockholm Academy of Dramatic Arts, examined the convention of Miss Julie and her compulsory suicide. On stage Pettersson asked angrily, "Why should Julie always have to kill herself? Why does Jean not commit suicide?" Since Jean also had sex with her, his shame and guilt ought to be as heavy as hers.

It is a question the audience carries home with them. Does Julie really have to die in the end? It seems to depend on one's point of view. The end is only half-explicit in the play: both Julie and Jean are hesitant, but when Jean admonishes Julie that, although it is terrifying, she has to go through with it, she numbly walks off-stage with the razor. There is a power and dramaturgic seduction in Strindberg's play that makes the audience hang on every word of Strindberg's, whether they like it or not. In order to oppose this force, Pettersson built in a certain distance between the stage and the audience. In an innovative, simultaneous approach that did not undermine the power of the play, she performed Miss Julie as a chain of segments in which she both acted out and reacted to today's challenges.

Another feminist project built on the theme of Miss Julie is FiaStina Sandlund's art film trilogy, Save Miss Julie: She's Blonde Like Me (2010), She's Staging It (20II), and She's Wild Again Tonight (2OI 5), focusing on a contemporary couple, Julie and Jean, living in New York. Sandlund is a feminist art activist who became known to a wider Swedish public in 200 I through the Slimy Old Men action (Gubbslem) in which she and fellow artist Joanna Rytel attacked the Miss Sweden beauty contest. Sandlund has been involved in performance and direct action ever since. For the role of Julie in the Saving Miss Julie project she chose Alexandra Dahlström, known from the film Show Me Love (I998), a groundbreaking examination of teenage lesbian love in a small Swedish town.

In Save Miss Julie: She's Blonde Like Me, Sandlund meets Dahlström at Arlanda airport in Stockholm for an audition. Three days later, they put on a performance at the Venice Art Biennale in the form of an interview. The two discuss Miss Julie and their own experiences as younger women, and find they have a lot in common with the characters they portray in the film. In the second part of the trilogy, She's Staging It, Dahlström travels to New York, where rehearsals of Sandlund's version of Miss Julie, 
She's Wild Again Tonight (a line from the play and also the title of the third part of the trilogy), are taking place. The screenplay is by Josefin Adolfsson, who wrote Lisa Aschan's film She Monkeys (20II). An African-American trans-butch actor, Lea Robinson, plays Jean. By bringing in female masculinity Robinson turns the play into a lesbian plot. This approach has been more popular in contemporary productions of Ibsen (Hedda Gabler has become a favorite lesbian character) than in performing Strindberg. The race-related dramaturgy had already been done in South Africa, again with a white Julie and a black Jean. A production in Canada sets the story in a native Canadian context.

Sandlund's Miss Julie is about power, but it is also about shame and sexuality. Although the trilogy is composed of art films, they are constructed in the action-documentary-analysis style Sandlund prefers. Her feminist conception shares its point of departure with that of Anna Pettersson. By rescuing Miss Julie from an obligatory suicide, both playwrights oppose the tradition of dead women's theatre. Feminists have become frustrated with this convention, which goes back to ancient Greek drama, where women were routinely murdered or sacrificed. ${ }^{3}$ When asked why a feminist activist like herself would bother to work with Strindberg's play, Sandlund responded:

People have questioned the fact that I am dealing with Strindberg, instead of dealing with one of his female colleagues. But it is not Strindberg himself who is interesting; it is our interpretations of his work that are exciting because I think he has great plays and stories. Strindberg was ahead of his time and saw these structures and these problems, although he had a different attitude towards them. So it is easy to identify with him. He felt that the personal was political: he was upset and questioned the existing power structures. ${ }^{4}$

Sandlund's mission is to rescue Miss Julie from death, and she characterizes her project by three key words: gender, comedy, and sadomasochism. The inspiration for her interpretation is taken from feminism and the psychoanalytic work of Jessica Benjamin, who also appears in the film She's Staging It. In addition to sexuality and shame, Sandlund considers class and gender to be the 
main themes of Miss Julie. She places the story in a contemporary setting and wants to show that these issues still persist for women.

Strindberg calls Julie a 'half-woman,' that is, a woman brought up to believe that she has the same rights and freedoms as a man, and this drives her to her death. 5 Sandlund, born in the I970s, reminds us that although "we now live in a feminist conscious society that claims to accept 'half women', there still remains tremendous resistance." ${ }^{6}$ She finds Miss Julie especially relevant because it deals with both class and gender. Sandlund identifies herself with the character of Julie and wants all the 'half women' to unite in a world where women believe they can become anything they want. "A hard awakening," Sandlund notes dryly.7

British director Katie Mitchell and video artist Leo Warner have created a strikingly radical interpretation of Miss Julie. The Schaubühne originally mounted their production in 20I0. It was among the main attractions of the Avignon Theatre Festival of 20I I, reaching Stockholm and the Bergman Festival in May 20 I 2. A young German ensemble performs Miss Julie in an impressive blend of film and theatre. The stage action is simultaneous, but not identical, with a film projected on a screen above it. Jean (Tilman Strauss), Julia (Louise Wolfram), and Kristin (Jule Böwe) enact Strindberg's tragedy in an atmospheric mansion kitchen as a technician selects certain film sequences and projects them on the screen. Combining performance, video, and live music on stage is an approach Mitchell and Warner have previously applied in productions of Virginia Woolf's Waves and Dostoyevsky's The Idiot at the National Theatre in London. They transform the stage into a movie studio, and the actors appear in close-ups on the screen.

The sequences in Miss Julie that are shown on the screen are full of Nordic nostalgia reminiscent of Ingmar Bergman. Bergman's influence over the play's visual composition becomes clearer when Miss Julie is performed in Sweden. Mitchell, who grew up with Bergman's films, has stated that the opportunity of working with Bergman's actors brought her to Sweden a few years ago to direct Easter, her first Strindberg production, at the Royal Dramatic Theatre in Stockholm. ${ }^{8}$

Mitchell and Warner's cinematic treatment opens new perspectives on Strindberg. Julie thrusts herself into the picture like a 
knife slipping in between Kristin and Jean. In one scene Kristin is alone in the foreground, looking out of a window, while Jean and Julie are preoccupied with each other in the background. While Kristin sleeps the ensemble takes the stage and creates a suggestive cinematic dream sequence that includes water and lighting effects. Gareth Fry's music, performed by the cellist Chloe Miller, dynamically unifies the mise-en-scène. ${ }^{9}$

In this interpretation, Miss Julie is filtered through Kristin, a working class woman, who changes the dynamic from traditional productions of the play. She rapturously picks midsummer flowers and looks on as the increasingly frivolous game between her unfaithful fiancé and the daughter of her upper-class employer intensifies. Alone in her room Kristin listens to them quarreling in the kitchen and is overcome with grief. ${ }^{\text {Iо }}$ By contrast, most productions depict Kristin as a woman of limited emotional range, as though her imagination could neither rise above the mundane nor be touched by any sense of romance or heartbreak.

While technology may tend to keep an audience at a distance, in this case frequent tight camera shots projected on the screen bring Kristin close to the audience: they see the reddened hands of a domestic worker, her drawn skin, tired eyes, and anguish as she overhears Jean in the act of betraying her. Theatergoers are drawn into her consciousness and see the drama through her eyes. In an unusual arrangement, three actors perform the role of Kristin. One sometimes takes up a position at a separate microphone and reads poems by Inger Christensen as Kristin's internal monologue. The production says little about who these three aspects of Kristin are. It is rather a midsummer night's rhapsody of emptiness where mute cameras register inner and outer actions on stage as a human tragedy unfolds.

None of the three multimedia productions described above are based on traditional conceptions. The technique of integrating film sequences has become a commonplace in contemporary theatre. The Swedish critic Leif Zern finds that this slights the work of actors: not only is the constant presence of electronic equipment stressful for the performers, but there are sometimes more screens than actors on stage. ${ }^{\text {II }}$

Nevertheless, technology used creatively in these productions 
has facilitated new interpretations. Mitchell says she wanted to stage something as technically sophisticated as a feature film in order to bring the story closer to the audience and disclose elements that may reawaken our interest in Strindberg. A breath of fresh air may just be what the performing arts need in a high-tech era where live theatre has ceased to be a priority for many people. The generation born just before the millennium lives in a transnational, mobile world linked via the Internet, while the performing arts remain linguistically and spatially bound to the local environment. Mitchell hopes that her productions will kindle enthusiasm among young audiences and draw them to the theatre, either as participants or spectators. ${ }^{\mathrm{I2}}$

Anna Pettersson, Fia-Stina Sandlund, and Katie Mitchell have succeeded in combining a vision of Strindberg with a creative application of technology. To the concern that technology may overwhelm actors, Mitchell responds, "I am attempting to keep the integrity of the live experience and also enhance the complexity and nuances." " 3 All three directors have envisioned the characters in Miss Julie in their unique ways. When Mitchell heard about Pettersson's one woman Miss, she exclaimed, “It's wonderful that the two of us, from two different countries, independently of each other, challenge Strindberg. He should not end up in a museum!" I4

\section{Notes}

I. Ring, “Genial Fröken Julie.” See also Strindberg, Miss Julie.

2. Zern, "Sju mustacher."

3. Cixious, "Aller à la mer."

4. Quoted in Gelin, "De vill rädda livet.”

5. Gustavsson, "Julie måste inte dö.”

6. Quoted in Gelin, "De vill rädda livet."

7. Ibid.

8. Ångström, "Multimedia ger Julie nytt liv.”

9. Zern, “Två sällsynta mästerverk.”

ı०. Benér, "Dramatisk urkraft bäddar.” 
I I. Zern, "Kroppen är teaterns hus.”

I 2. Ångström, "Multimedia ger Julie nytt liv."

I3. Ibid.

I4. Ibid.

\section{Works Cited}

Ångström, Anna. "Multimedia ger Julie nytt liv" (Multimedia Give Julie New Life). Svenska Dagbladet, Kultur, I3 May 20 I 2.

Benér, Theresa. "Dramatisk urkraft bäddar för nytolkningar" (Dramatic Primordial Beds for New Interpretations). Svenska Dagbladet, Kultur, 28 May 20 I 2.

Cixous, Hélène. "Aller à la mer.” Le Monde, 28 Apr 1977. English translation in Twentieth Century Theatre: A Sourcebook, edited by Richard Drain, I33-I35. London: Routledge, I 995.

Gelin, Martin. "De vill rädda livet på fröken Julie” (They Want to Rescue Miss Julie). Dagens Nyheter, Kultur, I 6 Oct 20 I I.

Gustavsson, Andreas. "Julie måste inte dö" (Julie Must Not Die). ETC Stockholm, I I May 2012.

Ring, Lars. "Genial Fröken Julie.” (A Brilliant Miss Julie). Svenska Dagbladet, 22 Apr 222012.

Strindberg, August. Miss Julie and Other Plays. Translated by Michael Robinson. Oxford: Oxford University Press, 2009.

Zern, Leif. "Kroppen är teaterns hus" (The Body Is the Home of Theatre). Dagens Nyheter, Kultur, Io Dec 2009.

. "Sju mustacher, tre hattar, men bara en skald." (Seven Mustasches, Three Hats, but Only One Author), Dagens Nybeter, Kultur, 22 Jan 2012. 